\begin{tabular}{|l|l|}
\hline Postprint Version & 1.0 \\
\hline Journal website & $\underline{\text { http://jtt.rsmjournals.com/content/early/2011/10/23/jtt.2011.110405.abstract }}$ \\
\hline Pubmed link & $\underline{\text { http://www.ncbi.nlm.nih.gov/pubmed/22025744 }}$ \\
\hline DOI & $10.1258 /$ jtt.2011.110405 \\
\hline
\end{tabular}

This is a NIVEL certified Post Print, more info at http://www.nivel.eu.

\title{
Costs and financial benefits of video communication compared to usual care at home: a systematic review.
}

José M PEeters*, PATRIEK MisTIAEN* AND ANNEKE L FRANCKE*†.

*Netherlands Institute for Health Services Research, Utrecht, The Netherlands;

†Department of Public and Occupational Health, EMGO Institute for Health and Care Research, VU

University Medical Center, Amsterdam, The Netherlands .

\begin{abstract}
SUMMARY
We conducted a systematic review of video communication in home care to provide insight into the ratio between the costs and financial benefits (i.e. cost savings). Four databases (PUBMED, EMBASE, COCHRANE LIBRARY, CINAHL) were searched for studies on video communication for patients living at home (up to December 2009). Studies were only included when data about the costs of video communication as well as the financial benefits were presented. The methodological quality of the included studies was assessed. Nine studies, mainly conducted in the US, met the inclusion criteria. The methodological quality was poor, except for one study. Most studies (8 of the 9) did not demonstrate that the financial benefits were significantly greater than the costs of video communication. One study - the only one with a high methodological quality - found that costs for patients who received video communication were higher than for patients who received traditional care. The review found no evidence that the cost of implementing video communication in home care was lower than the resulting financial benefits. More methodologically well conducted research is needed.
\end{abstract}

\section{INTRODUCTION .}

Video communication is a promising new health-care tool.

Several studies have shown that elderly and chronically ill patients may feel safer and may live independently for longer when they have a connection to a video communication system. ${ }^{1-3}$ In addition, the rapidly rising costs of health care in our ageing population necessitate a search for such innovations that are expected to be costeffective.

${ }^{4-7}$ Until now, video communication has often been delivered as a supplement to usual care. But in time, traditional home care may partly be replaced by care delivered by video communication, which may be costeffective.

Recently Wade et al. ${ }^{4}$ conducted a systematic review of cost-effectiveness studies of telehealth services using video communication for direct patient care. The review found that 22 of the 36 articles (61\%) concluded that delivery of telehealth services by video communication was less costly than the nontelehealth alternative, while the other studies found greater costs or mixed results. Wade et al. concluded that video communication was cost-effective for home care. However, they based their conclusions mainly on study authors' general statements, rather than on the results presented in the studies, and this may have biased the review's conclusions.

The questions addressed in the present review were:

(1) What research has already been conducted on the ratio between the costs and financial benefits of video communication in the care of independently living patients? 
(2) Does the research show that video communication results in reduced costs and increased financial benefits for health care as a whole and the (home) care organisations involved? The term 'financial benefits' means the avoided costs (at the level of the home-care organisation, the agency providing the intervention, the health insurer or the society) calculated by using video communication in comparison to usual care. Hence the main focus of the review was on costs and savings, rather than on patient outcomes. This choice was made, because there is considerable evidence about the positive effects of video communication on patient outcomes (e.g. less readmission in a hospital, increased self-management and patient satisfaction ${ }^{5-8}$ ).

\section{Methods .}

The systematic review was performed step-by-step. ${ }^{9}$ First, the following main databases for the subject of our study were searched:

(1) PUBMED (United States National Library of Medicine)

(2) EMBASE (Excerpta Medica Database)

(3) COCHRANE LIBRARY (Cochrane Database of Systematic Reviews, Cochrane Central Register of Controlled Trials, CochraneMethodology Register, Database of Abstracts of Reviews of Effects, Health Technology Assessment Database, NHS Economic Evaluation Database)

(4) CINAHL (Cumulative Index to Nursing and Allied Health Literature) The search strategies used for these databases are shown in Table 1.

In addition, reference lists of other systematic reviews ${ }^{1,4,8,10}$ were studied to identify other publications meeting the inclusion criteria. No limitations for year of publication or language of the publications were applied. All references were entered into a database (Reference Manager), where duplicate entries were removed. The searches were conducted in December 2009.

\section{Inclusion and exclusion criteria}

The references found were then assessed, to ascertain whether they were eligible for inclusion: first, based on the title and the abstract, and second based on the full text. The assessment was performed by two reviewers, independently of each other. Disagreements between the researchers concerning the inclusion and exclusion criteriawere resolved by discussion. The following inclusion criteria were used: (1) The study was aimed at video communication for patients living at home. Sheltered housing, e.g. for persons with disabilities, was also included.

(2) Patients were connected to a system of video communication with a home-care organisation or other care organisation.

(3) Thepublicationprovideddataonthecostsaswellasonthe financial benefits (cost savings) of video communication.

Studies in which video communication was part of a larger telecare system, for example video communication combined with telemonitoring of vital functions were included, when they presented data for the video communication separately. No limitations for patient groups or research designs were applied. Multiple publications about the same study were considered as a single study, for the purposes of the analysis.

The exclusion criteria were: (1) Studies that exclusively focused on video communication between care providers, or exclusively on video communication with informal carers or with parents of ill children.

(2) Studies in which only costs were examined, but no financial benefits were measured.

(3) Studies exclusively focusing on patient outcomes.

\section{Methodological assessment}

In the next step, the methodological quality of the included studies was assessed, using the checklist of Evers et al. for economic evaluations ${ }^{11}$, see Table 2. This checklist included 19 items (i.e. maximum score 19). Each item was formulated as a question and could be answered with yes (score 1 ) or no (score 0 ). For example: 'Is the economic study design appropriate to the stated objective?' and 'Have all important and relevant costs for each alternative been identified?' The assessment was conducted by two reviewers independently. 
The studies that used an economic model were also assessed using the checklist of Philips et al. ${ }^{12,13}$ This had a total of 55 items (i.e. maximum score 55) falling under the quality dimensions of Structure, Data and Consistency. Two reviewers also performed this assessment independently

\section{[TABLE 1 AND TABLE 2].}

\section{Data extraction}

Subsequently, the following data from the included studies were extracted: publication year, country of the research, nature of the intervention, type of care organisations that offer video communication, characteristics of the patient population, perspective from which costs and benefits were counted (e.g. from the perspective of the health-care system, home-care organisation, or society), national currency used, nature and extent of the costs, character and extent of the financial benefits, nature and extent of the effects for the patients, the analytical techniques used and the conclusion of the authors. The data extraction was conducted by one reviewer and checked by a second reviewer.

\section{RESULTS.}

The initial search resulted in 3681 hits. After removing duplicate articles, 3085 references remained. After we had selected references by reading titles and abstracts, there were 227 references to be judged for inclusion based on their full text. Screening of the references of the systematic reviews found did not yield additional references. Ultimately, 20 articles referring to nine different studies were selected for analysis. ${ }^{14-}$ ${ }^{33}$ The inclusion flow is shown in Figure 1.

\section{Study characteristics}

Eight of the nine studies were conducted in the USA and one in Spain (Table 3). The oldest publication was from 1995 and the most recent from 2009. Patient characteristics differed substantially from study to study: sometimes the intervention group was a select group, such as patients with obstructive sleep apnoea or patients with peritoneal dialysis.

Other studies were about chronic patients in general.

Two studies concerned only video communication. In five studies other telecare interventions were implemented, such as monitoring vital functions. In seven studies video communication was provided by a home-care organisation and in the other two studies it was provided by a hospital or other health-care facility. In all cases, the central front office (the other side of the video communication system) was staffed by nurses.

In all cases, video communication was offered as a pilot project and the period in which the patients could use video communication was 50-240 days per study. The frequency of contacts by video communication also differed for each study, ranging from 0.5-3 contacts/week.

\section{Methodological quality.}

Two studies used a model approach for a cost-benefit analysis, i.e. they estimated the equivalent monetary value of the benefits and the costs of home-telecare to establish whether they were worthwhile (Table 4). The other seven used an empirical approach: four of these studies used a randomized controlled design (RCT). The perspective of the analyses was described in four of the nine studies. In three studies, the perspective concerned the costs and financial benefits for the care institution that provided the video communication (in two studies the home-care organisation and in one study the hospital). In one study, the perspective concerned the costs and financial benefits for the health insurance company. In the other studies, the perspective had not been clearly indicated, but these studies presumably used the perspective of the care institution that offered the video communication.

The size of the research samples was 5-1068 in the intervention group and 25-1048 in the control group. Six studies had an intervention group of 100 patients or less. The methodological quality of eight out of the nine studies was obviously poor, as shown by the methodological assessment using the checklists. The 
degree of correspondence between the reviewers was high: the methodological scores given by both reviewers independently did not differ by more than one point.

The highest score of the reviewer per study or the least severe assessment of the methodological quality is shown in Table 4.

\section{COSTS AND FINANCIAL BENEFITS}

In most of the studies, the costs calculated concerned the costs of the equipment and the costs of the staff (mainly nurses) involved in the video communication (Table 5). The calculated benefits due to video communication mainly involved savings in travel expenses, savings in salaries because video interactions required less time, and savings connected with reduced costs for visits and admissions to care institutions.

\section{[Figure 1, TABLE 3 AND TABLE 4].}

The way that costs and benefits were calculated, in volume as well as in valuation, differed considerably between the studies and was generally not clear and/or was based on different assumptions. In the two studies which used an economic model, video communication resulted in savings, but the conclusions were not based on observed data. ${ }^{21,24}$ Six of the sevenstudies which did have observed data, did not findsignificant differences between the intervention groupand the control group, although the authors reached positive conclusions. Only one study, concerning video communication for diabetes patients, found a significant difference, although in the unexpected direction: the costs for patients who received video communication were $71-116 \%$ higher than for patientswho received conventional care. ${ }^{22}$ This study performed byMoreno et al. was the only one with a high methodological score. ${ }^{22}$ The results of this methodologically well-performed study are summarised in Box 1.

Three of the nine studies indicated that they also measured effectsonpatients, ${ }^{19,26,31}$ while the other studies did not state this clearly. The measured effects on patients included health status, quality of life, medication compliance, knowledge of the illness and patient satisfaction. The patients who had received video communication were found to be satisfied, in general. Regarding clinical effects, no study found significant differences between intervention groups and control groups.

\section{DISCUSSION.}

The present review identified nine studies (in 20 publications) of the costs and financial benefits of video communication delivered to independently living patients.

Eight of the nine studies were methodologically weak, which hampers statements about the ratio between costs and financial benefits. One study only was strong, from a methodological viewpoint. This study was performed in a relatively large sample of patients with diabetes and showed that the costs incurred by the health insurance company for the video communication group were significantly higher than for those for the control group. ${ }^{22}$ Reviews about the cost effectiveness of telehealth projects in general point to the often weak methodological quality of studies in this field. ${ }^{8,34,35}$ The majority of those studies dealt with smallscale pilot trials with small groups of patients. The subsequent implementation of these pilot studies does not commonly occur. Hence, no evidence exists that video communication results in cost savings (from the perspective of the home-care organisation, the agency providing the intervention, the health insurer or the society). A possible explanation might be that the costs of the technology are high in the short-term, while cost reductions may occur only over longer periods (say $5-10$ years).

Our conclusion about the lack of evidence contradicts the systematic review of Wade et al., which had a broad perspective and concluded 'that delivery of health services by real time video communication was cost-effective for home care'. ${ }^{4}$ The conclusions of Wade et al. are mainly based on the study authors' general conclusion rather than on the data presented, which may have biased the review's conclusion.We critically examined the data about costs and benefits in the included studies and in some cases ${ }^{17,26,27}$ we did not agree with the positive conclusions of these authors.

The contradictory conclusions may be also partially explained by differences in search strategies and inclusion criteria (e.g. Wade et al. ${ }^{4}$ excluded all studies that did not present health outcome data besides cost 
analyses). Because of the different time at which the reviews were performed, our review included the study of Moreno et al. ${ }^{22}$ but it was not included in the Wade review. The well performed study of Moreno et al. showed that the costs of the intervention group (video communication) were significantly higher than the control group (usual care), which is in the opposite direction from the conclusions of Wade et al.

Our review only included those studies that estimated costs as well as financial benefits. Studies that only measured patient outcomes were excluded from our research, since some previous reviews have already been done showing positive effects on, for instance, patient satisfaction. ${ }^{6}$ The studies included were mainly performed in the USA.Surprisingly only one study from outside the USA met our inclusion criteria, although comprehensive searches in four major databases were conducted. We performed data tracking in the reference lists of relevant systematic reviews, but this yielded no new references in addition to the references found in the literature databases. Hence, it is likely that we identified most of the relevant studies.

\section{[TABLE 5 AND BOX 1].}

\section{CONCLUSIONS}

The present review found no evidence that implementing video communication in patients living at home would be a cost-effective intervention. Future methodologically well conducted cost-effectiveness studies are needed, preferably with randomised controlled designs that are large enough to reach significance. It is also important to measure long-term costs and benefits, since cost savings may only occur in the long-term. Future studies should obtain outcome data on costs, such as the costs of nursing and medical staff, and of equipment. Information is also required on hospital admissions, travel costs and productivity.

Acknowledgements: We thank ActiZ for financing the study.

\section{REFERENCES.}

1 Hersh WR, Helfand M, Wallace J, et al. Clinical outcomes resulting from telemedicine interventions: a systematic review. BMC Med Inform Decis Mak 2001;1:5

2 Onor ML, Trevisiol M, Urciuoli O, et al. Effectiveness of telecare in elderly populations-a comparison of three settings. Telemed J E Health 2008;14:164-9

3 Botsis T, Hartvigsen G. Current status and future perspectives in telecare for elderly people suffering from chronic diseases. J Telemed Telecare 2008;14:195-203

4 Wade VA, Karnon J, Elshaug AG, Hiller JE. A systematic review of economic analyses of telehealth services using real time video communication. BMC Health Serv Res 2010;10:233

5 Botsis T, Demiris G, Pedersen S, Hartvigsen G. Home telecare technologies for the elderly. J Telemed Telecare 2008;14:333-7

6 Bowles $\mathrm{KH}$, Baugh AC. Applying research evidence to optimize telehomecare. J Cardiovasc Nurs 2007;22:5-15

7 Currell R, Urquhart C, Wainwright $P$, Lewis R. Telemedicine versus face to face patient care: effects on professional practice and health care outcomes. Cochrane Database Syst Rev 2000;CD002098

8 Bergmo TS. Can economic evaluation in telemedicine be trusted? A systematic review of the literature. Cost Eff Resour Alloc 2009;7:18

9 Wright RW, Brand RA, Dunn W, Spindler KP. How to write a systematic review. Clin Orthop Relat Res 2007;455:23-9

10 Gaikwad R, Warren J. The role of home-based information and communications technology interventions in chronic disease management: a systematic literature review. Health Informatics J 2009;15:122-46

11 Evers S, Goossens M, de Vet H, van Tulder M, Ament A. Criteria list for assessment of methodological quality of economic evaluations: Consensus on Health Economic Criteria. Int J Technol Assess Health Care 2005;21:240-5

12 Philips Z, Ginnelly L, Sculpher M, et al. Review of guidelines for good practice in decision-analytic modelling in health technology assessment. Health Technol Assess 2004;8:ii-iv, ix-xi, 1-158 
13 Philips Z, Bojke L, Sculpher M, Claxton K, Golder S. Good practice guidelines for decision-analytic modelling in health technology assessment: a review and consolidation of quality assessment.

Pharmacoeconomics 2006;24:355-71

14 Burdick AE, Mahmud K, Jenkins DP. Telemedicine: caring for patients across boundaries. Ostomy Wound Manage 1996;42:26-30, 32-4, 36-7

15 Study suggests video visits have significant cost, quality benefits. Dis Manag Advis 2002;8:44-7, 33

16 Remington L. Kaiser Permanente tele-home health research project shows positive results. Remington Report 2000;8:9-10

17 Smith CE, Cha JJ, Kleinbeck SV, Clements FA, Cook D, Koehler J. Feasibility of in-home telehealth for conducting nursing research. Clin Nurs Res. 2002;11(2):220-33

18 Barry H. Does video technology reduce costs effect satisfaction of home care patients? Evidence-Based Practice 2000;3:10

19 Jerant AF, Azari R, Martinez C, Nesbitt TS. A randomized trial of telenursing to reduce hospitalization for heart failure: patient-centered outcomes and nursing indicators. Home Health Care Serv Q 2003; 22:1-20

20 Johnston B. TeleHomecare: A payor's perspective. Top Spinal Cord Inj Rehabil 1999;5:66-69

21 Rumberger JS, Dansky K. Is there a business case for telehealth in home health agencies? Telemed J E Health 2006;12:122-7

22 Moreno L, Dale SB, Chen AY, Magee CA. Costs to Medicare of the Informatics for Diabetes Education and Telemedicine (IDEATel) home telemedicine demonstration: findings from an independent evaluation. Diabetes Care 2009;32:1202-4

23 Mahmud K, Lenz J. The personal telemedicine system. A new tool for the delivery of health care. J Telemed Telecare 1995;1:173-7

24 Kaye LW. Telemedicine: extension to home care. Telemed J 1997;3:243-6

25 Johnston B, Wheeler L, Deuser J. Kaiser Permanente Medical Center's pilot Tele-Home Health Project. Telemed Today 1997;5:16-7,19

26 Johnston B, Wheeler L, Deuser J, Sousa KH. Outcomes of the Kaiser Permanente Tele-Home Health Research Project. Arch Fam Med 2000;9:40-45

27 Jerant AF, Azari R, Nesbitt TS. Reducing the cost of frequent hospital admissions for congestive heart failure: a randomized trial of a home telecare intervention. Med Care 2001;39:1234-45

28 Harris G. Kaiser Permanente Tele-Home Health Research Project. Telemed Today 2000;8:34-6

29 Gallar P, Gutie'rrez M, Ortega O, et al. Telemedicine and follow up of peritoneal dialysis patients. Nefrologia 2006;26:365-71 [Spanish]

30 Gallar P, Vigil A, Rodriguez I, et al. Two-year experience with telemedicine in the follow-up of patients in home peritoneal dialysis. J Telemed Telecare 2007;13:288-92

31 Dansky KH, Palmer L, Shea D, Bowles KH. Cost analysis of telehomecare. Telemed J E Health 2001;7:225-32

32 Bowles $\mathrm{KH}$, Dansky KH. Teaching self-management of diabetes via telehomecare. Home Healthc Nurse 2002;20:36-42

33 Dansky KH, Bowles KH, Palmer L. How telehomecare affects patients. Caring 1999;18:10-4

34 Polisena J, Coyle D, Coyle K, McGill S. Home telehealth for chronic disease management: a systematic review and an analysis of economic evaluations. Int J Technol Assess Health Care 2009;25:339-49

35 Rojas SV, Gagnon MP. A systematic review of the key indicators for assessing telehomecare costeffectiveness. Telemed J E Health 2008;14:896-904 
Peeters, J.M., Mistiaen, P., Francke, A.L. Costs and financial benefits of video communication compared to usual care at home: a systematic review. Journal of Telemedicine and Telecare: 2011, 17(8), 403-411

\section{TABLES AND FIGURE}

Table 1 Search string

\begin{tabular}{|c|c|c|}
\hline Database & Search string & Number of hits \\
\hline PUBMED & $\begin{array}{l}\text { (video OR video* OR televis* OR TV OR camera OR webcam OR telecare OR telemedicine OR telehealth OR } \\
\text { telenursing OR tele homecare OR telehomecare OR tele-homecare OR tele-home-care OR 'Telemedicine'(Mesh)) } \\
\text { AND (home* OR house OR 'primary care') AND (('Costs and Cost Analysis'(Mesh) OR 'Economics'(Mesh) OR } \\
\text { 'Cost-Benefit Analysis'(Mesh)) OR cost* OR econom* OR dollar OR price OR money OR euro) }\end{array}$ & 898 \\
\hline EMBASE & $\begin{array}{l}\text { ('video'/syn OR video* OR televis* OR tv OR 'camera'/syn OR webcam OR telecare OR 'telehealth'/syn OR } \\
\text { 'telenursing'/syn OR 'tele homecare' OR telehomecare OR tele-homecare OR tele-home-care OR 'telemedicine'/ } \\
\text { syn) AND (home* OR house OR 'primary care'/syn) AND ('costs and cost analysis' } / \text { syn OR 'economics'/syn OR } \\
\text { 'cost-benefit analysis'/syn OR cost* OR econom* OR dollar OR price OR 'money'/syn OR euro) AND (embase)/lim }\end{array}$ & 1165 \\
\hline COCHRANE LIBRARY & $\begin{array}{l}\text { (video* OR televis* OR TV OR camera OR webcam OR telecare OR tele-care OR telemedicine OR tele-medicine OR } \\
\text { telehealth OR tele-health OR telenursing OR tele-nursing OR 'tele homecare' OR telehomecare OR tele-homecare } \\
\text { OR tele-home-care) AND (home* OR house OR 'primary care' OR 'community medicine') AND (cost* OR econom* } \\
\text { OR dollar OR price OR money OR euro) in Cochrane Reviews, Other Reviews, Clinical Trials, Methods Studies, } \\
\text { Technology Assessments and Economic Evaluations }\end{array}$ & 606 \\
\hline CINAHL & $\begin{array}{l}\text { (M) telemedicine or MJ telenursing or TX video* or TX televis* or TX TV or TX camera or TX telecare or TX tele-care or } \\
\text { TX telehealth or TX tele-health or TX tele-nursing or TX tele-medicine OR TX 'tele homecare' OR TX telehomecare } \\
\text { OR TX tele-homecare OR TX tele-home-care ) AND (MJ 'Home Nursing' or TX 'community care' or TX 'primary } \\
\text { care' or TX house or TX home*) AND (M] 'Cost Benefit Analysis' or TX cost" or TX econom* or TX price) }\end{array}$ & 1012 \\
\hline Total & & 3681 \\
\hline
\end{tabular}

Table 2 Checklist of Evers et al. ${ }^{11}$

\section{YES NO}

Is the study population clearly described?

Are competing alternatives clearly described?

Is a well-defined research question posed in answerable form?

Is the economic study design appropriate to the stated objective?

Is the chosen time horizon appropriate in order tot include relevant

costs and consequences?

Is the actual perspective chosen appropriate?

Are all important and relevant costs for each alternative identified?

Are all costs measured appropriately in physical units?

Are costs valued appropriately?

Are all important and relevant outcomes for altemative identified?

Are all outcomes measured appropriately?

Are outcomes valued appropriately?

Is an incremental analysis of costs and outcomes of alternatives performed?

Are all future costs and outcomes discounted appropriately?

Are all important variables, whose values are uncertain, appropriately subjects to sensitivity analysis?

Do the conclusions follow from the data reported?

Does the study discuss the generalizability of the results to other settings and patient/client groups?

Does the article indicate that there is no potential conflict of interest of study researcher(s) and funder(s)?

Are ethical and distributional issues discussed appropriately? 
Peeters, J.M., Mistiaen, P., Francke, A.L. Costs and financial benefits of video communication compared to usual care at home: a systematic review. Journal of Telemedicine and Telecare: 2011, 17(8), 403-411

Figure 1 Flow chart of study inclusions

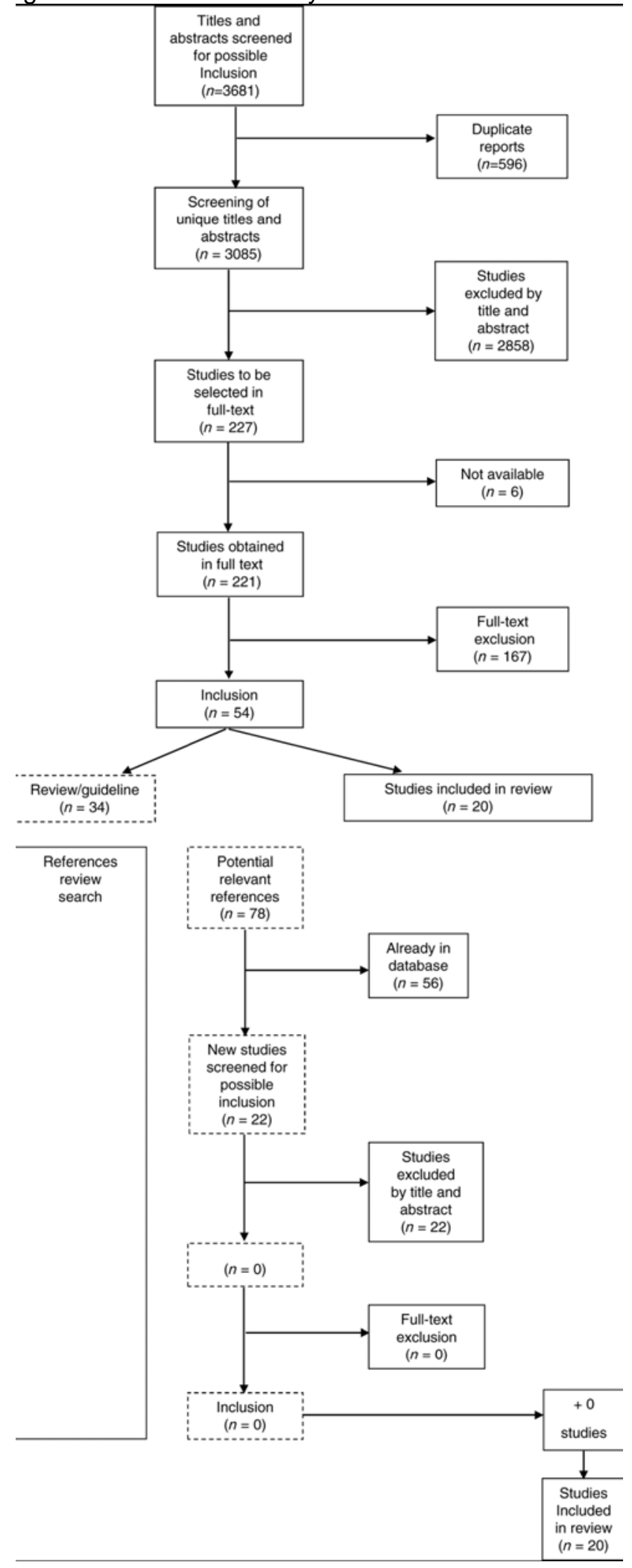




\begin{tabular}{|c|c|c|c|c|c|c|c|c|}
\hline $\begin{array}{l}\text { Study/ } \\
\text { References }\end{array}$ & $\begin{array}{l}\text { Year of } \\
\text { publication }\end{array}$ & Country & Patient category & $\begin{array}{l}\text { Who delivers video } \\
\text { communication? }\end{array}$ & Type of video communication system & $\begin{array}{l}\text { Telecare system only for } \\
\text { video communication? }\end{array}$ & $\begin{array}{l}\text { Duration of video } \\
\text { communication } \\
\text { (average, in days) }\end{array}$ & $\begin{array}{l}\text { (average per } \\
\text { patient per } \\
\text { period) }\end{array}$ \\
\hline Dansky ${ }^{15,31-33}$ & 2001 & USA & $\begin{array}{l}\text { Diabetic patients discharged from } \\
\text { the hospital who need nursing } \\
\text { home care. }\end{array}$ & Home-care organisation (nurses). & $\begin{array}{l}\text { The patient station had a camera with a } \\
\text { close-up lens, medical sensors } \\
\text { (sphygmomanometer and } \\
\text { stethoscope), and two large buttons } \\
\text { (no-keyboard) for patient response to } \\
\text { audio/visual cues. The clinical station } \\
\text { was a PC with a keyboard and mouse } \\
\text { that allowed the nurse to manipulate } \\
\text { the image required by the patient } \\
\text { camera and capture still images for } \\
\text { medical use. The patient station and } \\
\text { clinical station were linked together } \\
\text { over ordinary telephone lines via a } \\
\text { standard modem. }\end{array}$ & $\begin{array}{l}\text { No. Also measurement } \\
\text { and transmission of } \\
\text { body temperature, } \\
\text { weight, blood glucose } \\
\text { and pulse oximetry. }\end{array}$ & 50 & $5.5(4)$ of $9(7)$ \\
\hline Gallar $^{29,30}$ & 2007 & Spain & $\begin{array}{l}\text { Stable patients undergoing } \\
\text { peritoneal dialysis at home. }\end{array}$ & Hospital (dialysis nurses). & $\begin{array}{l}\text { The videoconference equipment in the } \\
\text { patient's home was connected to the } \\
\text { patients' TV set. At the hospital, a PC } \\
\text { with a videoconference card and } \\
\text { software allowed control of the } \\
\text { patients' camera. The connection } \\
\text { between the hospital and the patient's } \\
\text { home was through three ISDN lines. } \\
\text { Some patients with automated dialysis } \\
\text { also had a modem for transmitting the } \\
\text { data from the dialysis device to the } \\
\text { hospital. }\end{array}$ & Yes. & 240 & 7.0 \\
\hline Jerant $^{19,27}$ & 2001 & USA & $\begin{array}{l}\text { English-speaking patients, } 40 \\
\text { years of age and older } \\
\text { discharged from the hospital, } \\
\text { who had a primary hospital } \\
\text { admission diagnosis of } \\
\text { Congestive Heart Failure (CHF). }\end{array}$ & $\begin{array}{l}\text { Hospital (an in-person home } \\
\text { nurse visit shortly after } \\
\text { discharge and a second } \\
\text { in-home nurse visit } \\
\text { approximately } 60 \text { days later. A } \\
\text { single study nurse conducted } \\
\text { nearly all the home visits). }\end{array}$ & $\begin{array}{l}\text { A personal telecare unit was installed at } \\
\text { the initial in-person visit, with a small } \\
\text { camera, a microphone and an } \\
\text { electronic stethoscope. The units } \\
\text { operated over ordinary telephone lines } \\
\text { and allowed videoconferences with the } \\
\text { study nurse at the medical centre. }\end{array}$ & $\begin{array}{l}\text { No. Also lung auscultation } \\
\text { via an electronic } \\
\text { stethoscope. }\end{array}$ & 62 & 9.3 \\
\hline Johnston ${ }^{20,25,26}$ & 2000 & USA & $\begin{array}{l}\text { Newly referred patients diagnosed } \\
\text { as having congestive heart } \\
\text { failure, chronic obstructive } \\
\text { pulmonary disease (COPD), } \\
\text { cerebral vascular accident, } \\
\text { cancer, diabetes, anxiety, or } \\
\text { need for wound care. }\end{array}$ & $\begin{array}{l}\text { Home health-care setting } \\
\text { (designated TeleHealth } \\
\text { Nurses). }\end{array}$ & $\begin{array}{l}\text { The video communication system } \\
\text { operated over ordinary telephone lines. } \\
\text { The peripheral units included a } \\
\text { stethoscope, digital blood pressure } \\
\text { machine, and a magnifying lens that } \\
\text { attached to the camera for close-up } \\
\text { viewing. The nurse had a headset at the } \\
\text { receiving station to hear lung, cardiac, } \\
\text { or bowel sounds. A second telephone } \\
\text { line was necessary for using the } \\
\text { analogue stethoscope. }\end{array}$ & $\begin{array}{l}\text { No. The video system } \\
\text { included peripheral } \\
\text { equipment for assessing } \\
\text { cardiopulmonary } \\
\text { status. }\end{array}$ & 53 & 3.9 \\
\hline
\end{tabular}


$\overline{\bar{u}}$ Table 3 Continued

\begin{tabular}{|c|c|c|c|c|c|c|c|c|}
\hline 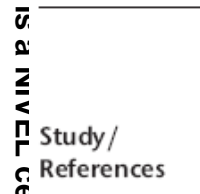 & $\begin{array}{l}\text { Year of } \\
\text { publication }\end{array}$ & Country & Patient category & $\begin{array}{l}\text { Who delivers video } \\
\text { communication? }\end{array}$ & Type of video communication system & $\begin{array}{l}\text { Telecare system only for } \\
\text { video communication? }\end{array}$ & $\begin{array}{l}\text { Duration of video } \\
\text { communication } \\
\text { (average, in days) }\end{array}$ & $\begin{array}{l}\text { Number of } \\
\text { contacts } \\
\text { (average per } \\
\text { patient per } \\
\text { period) }\end{array}$ \\
\hline Kaye $^{24}$ & 1997 & USA & $\begin{array}{l}\text { Home-care patients of all ages } \\
\text { who need nursing home care. }\end{array}$ & Home-care organisation (nurses). & Commercial unit. & Not specified. & Not applicable. & $\begin{array}{l}\text { Not } \\
\text { applicable. }\end{array}$ \\
\hline 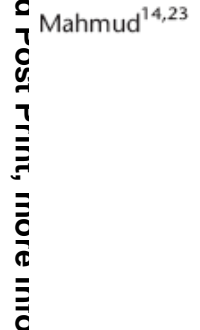 & 1995 & USA & $\begin{array}{l}\text { Patients with several chronic } \\
\text { diseases who need nursing } \\
\text { home care. }\end{array}$ & $\begin{array}{l}\text { Home-care organisation } \\
\text { (home-care nurses). }\end{array}$ & $\begin{array}{l}\text { The central station included a receiver to } \\
\text { identify incoming calls, a video screen } \\
\text { for the health-care staff, and the } \\
\text { listening end of the electronic } \\
\text { stethoscope, the patient's chart of } \\
\text { electronic records, a close-up lens and a } \\
\text { button to check vital functions. The } \\
\text { central site also had a PC and a storage } \\
\text { device for the patient's electronic } \\
\text { home-care records. }\end{array}$ & $\begin{array}{l}\text { No. Also auscultation and } \\
\text { monitoring of vital } \\
\text { functions. }\end{array}$ & 87 & 15.4 \\
\hline ن̀n Moreno $^{22}$ & 2009 & USA & Type 2 diabetes living at home. & Nurse case managers. & $\begin{array}{l}\text { The home telemedicine unit was a PC } \\
\text { connected to an ordinary telephone } \\
\text { line, with a monitor, keyboard and } \\
\text { mouse, video camera, speakers, } \\
\text { microphone, glucose and blood } \\
\text { pressure meters. }\end{array}$ & $\begin{array}{l}\text { No. Also glucose and } \\
\text { blood pressure } \\
\text { measurement. }\end{array}$ & Not specified. & Not specified. \\
\hline Rumberger 21 & 2006 & USA & $\begin{array}{l}\text { Patients who need nursing home } \\
\text { care (not further specified). }\end{array}$ & Home-care organisation (nurses). & Not specified. & Not specified. & Not applicable. & $\begin{array}{l}\text { Not } \\
\text { applicable. }\end{array}$ \\
\hline 离 Smith17 & 2002 & USA & $\begin{array}{l}\text { Adult patients, living at home, } \\
\text { using night-time mechanical } \\
\text { ventilators for obstructive sleep } \\
\text { apnoea and their home } \\
\text { caregivers. }\end{array}$ & $\begin{array}{l}\text { Home-care organisation } \\
\text { ( } 1 \text { telehealth nurse conducted } \\
\text { all the telehealth visits). }\end{array}$ & $\begin{array}{l}\text { The telehealth equipment included a } \\
\text { camera and modem mounted in top of } \\
\text { the television. The camera had a } \\
\text { wide-angle lens and a number of image } \\
\text { control features. The central site could } \\
\text { control the camera at home. The } \\
\text { telehealth unit was connected through } \\
\text { an ordinary telephone line. }\end{array}$ & Yes & 180 & 23 \\
\hline
\end{tabular}


Peeters, J.M., Mistiaen, P., Francke, A.L. Costs and financial benefits of video communication compared to usual care at home: a systematic review. Journal of Telemedicine and Telecare: 2011, 17(8), 403-411

Table 4 Type of studies and methodological assessment

\begin{tabular}{|c|c|c|c|c|c|}
\hline Study & Type of study & Perspective & $\begin{array}{l}\text { Total N ( } n \text { Intervention (I)/ } \\
n \text { Control group (C) }\end{array}$ & $\begin{array}{l}\text { Score on Evers check list } \\
(\max =19)\end{array}$ & $\begin{array}{l}\text { Score on Phillips } \\
(\max =55)\end{array}$ \\
\hline Dansky & Empirical trial (RCT) & $\begin{array}{l}\text { Home-care organisation } \\
\text { (stated) }\end{array}$ & $171(86 \mathrm{I} / 85 \mathrm{C})$ & 6 & Not applicable \\
\hline Gallar & $\begin{array}{l}\text { Empirical trial (comparative; } \\
\text { no randomisation) }\end{array}$ & Hospital (probably) & $57(25 \mathrm{l} / 32 \mathrm{C})$ & 1 & Not applicable \\
\hline Jerant & Empirical trial (RCT) & Hospital (stated) & $37(12 \mathrm{l} / 25 \mathrm{C})$ & 7 & Not applicable \\
\hline Johnston & Empirical trial $(\mathrm{RCT})$ & $\begin{array}{l}\text { Home-care organisation } \\
\text { (probably) }\end{array}$ & $212(102 \mathrm{I} / 110 \mathrm{C})$ & 1 & Not applicable \\
\hline Kaye & Model & $\begin{array}{l}\text { Home-care organisation } \\
\text { (probably) }\end{array}$ & Not applicable & 1 & 3 \\
\hline Mahmud & Empirical trial (no control group) & $\begin{array}{l}\text { Home-care organisation } \\
\text { (probably) }\end{array}$ & $12(12 \mathrm{l} / 0 \mathrm{C})$ & 0 & Not applicable \\
\hline Moreno & Empirical trial $(\mathrm{RCT})$ & Health Insurance (stated) & $2169(1093 \mathrm{I} / 1076 \mathrm{C})$ & 17 & Not applicable \\
\hline Rumberger & Model & $\begin{array}{l}\text { Home-care organisation } \\
\text { (stated) }\end{array}$ & Not applicable & 5 & 22 \\
\hline Smith & Empirical trial (no control group) & $\begin{array}{l}\text { Home-care organisation } \\
\text { (probably) }\end{array}$ & $5(5 \mathrm{l} / \mathrm{0} \mathrm{C})$ & 1 & Not applicable \\
\hline
\end{tabular}


Peeters, J.M., Mistiaen, P., Francke, A.L. Costs and financial benefits of video communication compared to usual care at home: a systematic review. Journal of Telemedicine and Telecare: 2011, 17(8), 403-411

Table 5 Patients' outcomes and balance costs versus financial benefits

\begin{tabular}{|c|c|c|c|c|c|}
\hline Study & $\begin{array}{l}\text { Measured patient } \\
\text { outcomes } \\
\text { (instrument) }\end{array}$ & $\begin{array}{l}\text { Evidence } \\
\text { patient } \\
\text { outcomes }\end{array}$ & Measured financial investment costs & $\begin{array}{l}\text { Measured financial } \\
\text { benefits }\end{array}$ & Balance costs versus financial benefits \\
\hline Dansky & $\begin{array}{l}\text { - health status } \\
\text { (Oasis) } \\
\text { - quality of life } \\
\text { (SF-36) } \\
\text { - patient satisfaction } \\
\text { (self-developed) }\end{array}$ & $\begin{array}{l}\text { - no data } \\
\text { - no data } \\
\text { - generally } \\
\text { satisfied }\end{array}$ & $\begin{array}{l}\text { - nursing costs } \\
\text { - costs implementation video } \\
\text { communication (training and } \\
\text { meeting) } \\
\text { - equipment costs } \\
\text { - administrative overhead }\end{array}$ & - saved hospital visits & $\begin{array}{l}\text { Unclear, because of lack of data about the } \\
\text { control group; probably video } \\
\text { communication is more expensive than } \\
\text { control group, receiving usual care }\end{array}$ \\
\hline Gallar & Not indicated & Not assessable & $\begin{array}{l}\text { - staff costs } \\
\text { - pharmaceuticals } \\
\text { - hospital space } \\
\text { - equipment costs } \\
\text { - telephone costs }\end{array}$ & $\begin{array}{l}\text { - differences in costs as } \\
\text { presented } \\
\text { - saved travel costs }\end{array}$ & $\begin{array}{l}\text { Video communication is more expensive } \\
\text { than control group, receiving usual care }\end{array}$ \\
\hline Jerant & $\begin{array}{l}\text { - self-management } \\
\text { (unknown) } \\
\text { - medication } \\
\text { adherence } \\
\text { (unknown) } \\
\text { - health status } \\
\text { (MLHFQ, SF-36) } \\
\text { - patient satisfaction } \\
\text { (self-developed) }\end{array}$ & $\begin{array}{l}\text { - no difference } \\
\text { - no difference } \\
\text { - no difference } \\
\text { - no difference }\end{array}$ & $\begin{array}{l}\text { - nursing costs } \\
\text { - equipment costs }\end{array}$ & $\begin{array}{l}\text { - differences in costs as } \\
\text { mentioned } \\
\text { - costs Emergency } \\
\text { Department (ED) } \\
\text { visits } \\
\text { - hospital readmission } \\
\text { charges } \\
\text { - costs total charges } \\
\text { (all-cause } \\
\text { readmissions) }\end{array}$ & $\begin{array}{l}\text { No differences found (because of small } \\
\text { numbers) }\end{array}$ \\
\hline Johnston & $\begin{array}{l}\text { - medication } \\
\text { compliance } \\
\text { (self-developed) } \\
\text { - illness knowledge } \\
\text { (self-developed) } \\
\text { - self management } \\
\text { (self-developed) } \\
\text { - patient satisfaction } \\
\text { (self-developed) }\end{array}$ & $\begin{array}{l}\text { - no difference } \\
\text { - no difference } \\
\text { - no difference } \\
\text { - majority is } \\
\text { satisfied }\end{array}$ & $\begin{array}{l}\text { - nursing costs } \\
\text { - travel costs } \\
\text { - equipment costs } \\
\text { - telephone costs }\end{array}$ & $\begin{array}{l}\text { - differences in costs as } \\
\text { presented } \\
\text { - costs for physician } \\
\text { visits } \\
\text { - cost for emergency } \\
\text { department visits } \\
\text { - hospital costs }\end{array}$ & $\begin{array}{l}\text { Not very clear, but perhaps no difference or } \\
\text { probably video communication is more } \\
\text { expensive than control group, receiving } \\
\text { usual care }\end{array}$ \\
\hline Kaye & Not indicated & Not assessable & $\begin{array}{l}\text { - wages } \\
\text { - travel costs } \\
\text { - equipment costs }\end{array}$ & $\begin{array}{l}- \text { increase in } \\
\text { productivity }\end{array}$ & $\begin{array}{l}\text { Unclear and uncertain assumptions, but } \\
\text { according to the authors' model video } \\
\text { communication could be cheaper than } \\
\text { control group, receiving usual care, due to } \\
\text { increase in productivity }\end{array}$ \\
\hline Mahmud & Not indicated & Not assessable & - equipment costs & - hospital costs & Unknown; no control group, just assumptions \\
\hline Moreno & Not indicated & Not assessable & $\begin{array}{l}\text { - costs for design stage, } \\
\text { implementation stage and closeout } \\
\text { stage (de-installation) of the video } \\
\text { communication system } \\
\text { - research related costs } \\
\text { - intervention-related costs }\end{array}$ & $\begin{array}{l}\text { - differences in } \\
\text { expenditures for } \\
\text { medicare-covered } \\
\text { services }\end{array}$ & $\begin{array}{l}\text { Video communication was significantly more } \\
\text { expensive than usual care (between } \\
71 \text { and } 116 \% \text { higher) }\end{array}$ \\
\hline Rumberger & Not indicated & Not assessable & $\begin{array}{l}\text { - equipment costs } \\
\text { - training and on-going costs } \\
\text { - skilled nursing costs }\end{array}$ & $\begin{array}{l}\text { - increase in } \\
\text { productivity }\end{array}$ & $\begin{array}{l}\text { Unclear and uncertain } \\
\text { assumptions; but according to the authors' } \\
\text { model, video communication could be } \\
\text { cheaper than control group, receiving usual } \\
\text { care }\end{array}$ \\
\hline Smith & Not indicated & Not assessable & $\begin{array}{l}\text { - equipment costs } \\
\text { - nursing costs } \\
\text { - travel costs for installation and } \\
\text { pick-up }\end{array}$ & -travel costs & $\begin{array}{l}\text { Unclear and uncertain } \\
\text { assumptions; but according to the authors' } \\
\text { model, video communication could be } \\
\text { cheaper than control group, receiving } \\
\text { usual care }\end{array}$ \\
\hline
\end{tabular}


Peeters, J.M., Mistiaen, P., Francke, A.L. Costs and financial benefits of video communication compared to usual care at home: a systematic review. Journal of Telemedicine and Telecare: 2011, 17(8), 403-411

Box 1 Summary of the results of the study of Moreno et $a l^{22}$

Patients living in two medically under-served areas of New York between 2000 and 2007 were randomised to nurse management via telemedicine ( $n=1068)$ or usual care $(n=1048)$. Treatment group members were provided with a home telemedicine unit and trained in its use. They used the home telemedicine unit to (1) monitor blood glucose and blood pressure (2) interact with a nurse case manager through scheduled videoconferences and (3) access web-based educational materials. The treatment and control group members were similar on all baseline characteristics, as expected with random assignment. The savings in total Medicare expenditures were too small to offset the high costs of the intervention. The total costs were $71-116 \%$ higher for the treatment group than for the control group. 